T. Martin Barrat, Elis D. Avner, William E. Harmon (eds.)

\section{Pediatric Nephrology}

Lippincott, Philadelphia/Williams \& Wilkins, Baltimore 1999 1412 pp; USD 189.00

ISBN 0-683-30055-5

This single volume, massive in its content, is the 4th edition of what has become a classic textbook of pediatric nephrology. It is, as would be expected, a multiauthor, international work with many of the stars of pediatric nephrology contributing. The book is divided into 13 sections, each of which has 5-16 chapters in it. The sections cover every aspect of pediatric nephrology in a most comprehensive and up to date manner from embryology through anatomy and physiology to a final section devoted to physiology around the world. There is no major aspect of pediatric nephrology which is not cov- ered ably and in detail. The book is a pleasure to read, but for one drawback - the preference for black and white photographs over color, including histology. This obviously keeps the price down to its ridiculously low level for a comprehensive work of this kind, but it seems to me that for a few dollars more, color photographs would be very useful to the reader. It is a book which all pediatric nephrologists should possess, and I also recommend it for trainees in adult nephrology as well as in pediatric nephrology. Indeed it is desirable that adult nephrologists possess this book, if they engage in clinical nephrology, for one is always being called upon to express an opinion when the pediatric nephrologist is absent, and a deeper knowledge of pediatric nephrology can be acquired from this book at a very modest price. The editors are to be congratulated for having assembled this splendid book.

G.M. Berlyne

\section{KARGER}

(c) 2000 S. Karger AG, Basel

Fax +41613061234

E-Mail karger@karger.ch www. karger.com
Accessible online at: www. karger.com/journals/nef 